\title{
PERHITUNGAN GAJI REMUNERASI PADA PENGADILAN NEGERI KELAS 1B MENGGUNAKAN ALGORITMA JST
}

\section{Herlina}

Program Studi Teknik Informatika

Fakultas Ilmu Komputer, Universitas Al Asyariah Mandar, Polewali, Indonesia herlinaisme@gmail.com

\begin{abstract}
ABSTRAK
Tujuan penelitian ini adalah untuk membangun sebuah system perhitungan gaji remunerasi pada Pengadilan Negeri Kelas 1B menggunakan algoritma Jaringan Syaraf Tiruan (JST). Penetapan besaran kompensasi remunerasi didasarkan oleh aktivitas proses kerja sehari-hari dalam hal ini diwakili oleh variabel absen pegawai. Model arsitektur JST yang digunakan adalah jaringan lapisan tunggal.
\end{abstract}

Kata Kunci-Algoritma Jaringan Syaraf Tiruan, Reumenerasi.

ABSTRACT

The purpose of this study was to build a remuneration salary calculation system in the Class $1 B$ District Court using the Artificial Neural Network (ANN) algorithm. Determination of the amount of remuneration compensation is based on the activities of the daily work process in this case represented by employee absent variables. The ANN architecture model used is a single layer network.

Keywords-Artificial Neural Network Algorithm, Reumeneration 
Jurnal Ilmiah Ilmu Komputer Vol. 5, No. 2, April 2019

Fakultas Ilmu Komputer

Universitas AL Asyariah Mandar

\section{PENDAHULUAN}

Pemerintah sedang gencar-gencarnya melakukan perbaikan atau reformasi birokrasi termasuk dalam hal peningkatan kualitas pelayanan aparat-aparatnya. Berdasarkan hasil survey ditemukan bahwa salah satu penyebab merosotnya pelayanan dan meningkatnya kuantitas korupsi disebabkan karena selama ini gaji PNS dianggap masih kurang kompetitif dibanding gaji karyawan swasta, serta besaran gaji PNS tidak dikaitkan dengan kompetensi dan prestasi kerja melainkan pangkat dan masa kerja[1].

Untuk itu, pemerintah mencoba memotivasi kinerja pegawai negeri sipil (PNS) dalam meningkatkan prestasi kerjanya dengan memberikan kompensasi dalam bentuk tambahan gaji yang dikenal dengan sebutan remunerasi[2]. Tetapi sampai saat ini pemberian remunerasi masih terbatas pada kementrian/lembaga penegak hukum dan keuangan, selebihnya masih menunggu keputusan dari dewan perwakilan rakyat.

Pada prakteknya, penetapan ini mengalami berbagai kendala disebabkan kekompleksan perhitungan kenaikan besaran remunerasi tersebut, karena kenaikan remunerasi didasarkan pada kelayakan, logika, rasional dan dapat dipertanggungjawabkan serta menyangkut emosional dari aspek karyawan. Salah satu contoh aspek yang sangat mempengaruhi besaran nilai remunerasi adalah nilai absen harian [3].

Diperlukan sebuah system yang berbasis komputer dengan metode-metode yang tepat agar dapat memudahkan petugas pengambil keputusan dalam menetapkan besaran remunerasi yang diperoleh tiap-tiap pegawai. Penelitian ini dibatasi hanya pada perhitungan remunerasi Pengadilan Negeri (PN) kelas 1B yang berada dibawah naungan Mahakamah Agung. Dan dalam penyelesaiannya digunakan metode algoritma JST.

\section{TINJAUAN PUSTAKA}

\subsection{Remunerasi}

Menurut Wikipedia, remunerasi berarti pembelian hadiah (pengahrgaan atas jasa dsb) atau imbalan dimana pemerintah menentapkan peraturan khusus mengenai remunerasi kepada pegawai negeri sipil[3]. Komisi dan Kompensasi pada dasarnya memiliki tujuan yang sama yaitu memberikan motivasi kepada tenaga kerja untuk meningkatkan prestasi kerja, serta efisiensi dan efektivitas produksi. Oleh karena itu, bila kompensasi diberikan secara benar, para karyawan akan lebih terpuaskan dan termotivasi untuk mencapai sasaran-sasaran organisasi[4]

\subsection{Algoritma JST}

\subsubsection{Konsep JST}

Jaringan Syaraf Tiruan merupakan salah satu representasi buatan dari otak manusia yang selalu mencoba untuk mensimulasikan proses pembelajaran pada otak manusia tersebut. Istilah buatan digunakan karena jaringan syaraf ini diimplementasikan dengan menggunakan program sistem pakar yang mampu menyelesaikan sejumlah proses perhitungan selama proses pembelajaran [1].

Jaringan saraf Tiruan adalah merupakan salah satu representasi buatan dari otak manusia yang selalu mencoba untuk mensimulasikan proses pembelajaran pada otak manusia tersebut. Istilah buatan disini digunakan karena jaringan saraf ini diimplemintasikan dengan menggunakan program komputer yang mampu menyelesaikan sejumlah proses perhitungan selama proses pembelajaran.

Hal yang perlu mendapat perhatian istimewa adalah bahwa jaringan saraf tiruan tidak diprogram untuk menghasilkan keluaran tertentu. Semua keluaran atau kesimpulan yang ditarik oleh jaringan didasarkan pada pengalamannya selama mengikuti proses pembelajaran. Pada proses pembelajaran, ke dalam jaringan saraf tiruan dimasukkan pola-pola input dan output lalu jaringan akan diajari untuk memberikan jawaban yang bias diterima[2].

\subsubsection{Komponen JST}

Komponen dalan JST, adalah sebagai berikut :

a) Neuron, sel syaraf yang akan mentransformasikan informasi yang diterima melalui sambungan keluarnya menuju neuron-neuron yang lain.

b) Pada jaringan syaraf, hubungan antar neuron-neuron dikenal dengan nama bobot.

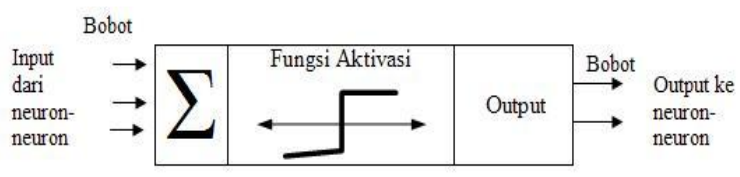

Gambar 1. Hubungan antar neuron (bobot)

c) Pada jaringan syaraf, neuron-neuron akan dikumpulkan dalam lapisan-lapisan (layer) yang disebut dengan lapisan neuron (neuron layers).

d) Informasi yang diberikan pada jaringan syaraf akan dirambatkan lapisan kelapisan, mulai dari input sampai kelapisan output melalui lapisan yang lainnya, yang dikenal dengan lapisan tersembunyi (hidden layer), tergantung pada algoritma pembelajarannya, bias jadi informasi tersebutakan dirambatkan secara mundur pada jaringan lapisan [5].

\subsubsection{Arsitektur JST}

Arsitektur JST terdiri atas :

a) Faktor terpenting untuk menentukan kelakuan suatu neuron adalah fungsi aktivasi dan pola bobotnya.

b) Ada beberapa arsitektur jaringan syaraf, antara lain : Jaringan dengan lapisan tunggal (single layer net)

- Hanya memiliki satu lapisan dengan bobot-bobot terhubung. 
- Jaringan ini hanya menerima input kemudian secara langsung akan mengolahnya menjadi output tanpa harus melalui lapisan

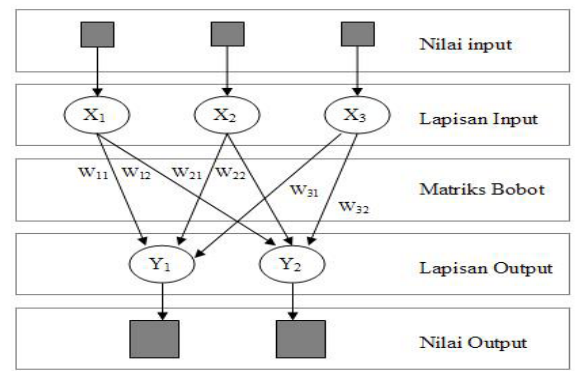

Gambar 2. Single Layer Net

Jaringan dengan banyak lapisan (multilayer net)

- Memiliki 1 atau lebih lapisan yang terletak diantara lapisan input dan lapisan output.

- Ada lapisan yang berbobot yang terletak antara 2 lapisan yang bersebelahan.

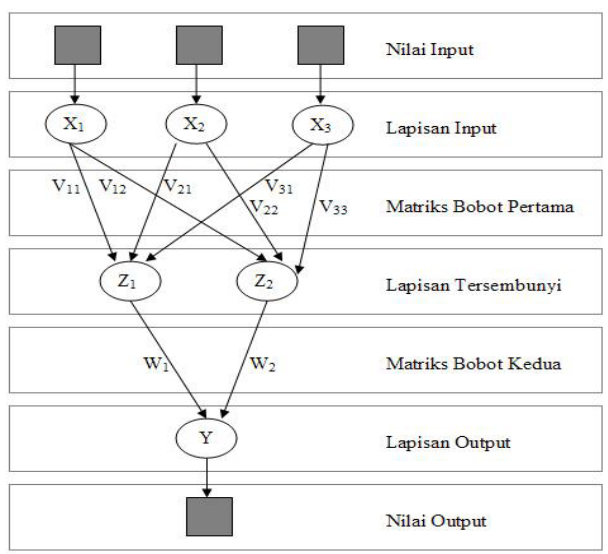

Gambar 3. Multilayer Net

\section{METODE YANG DIUSULKAN}

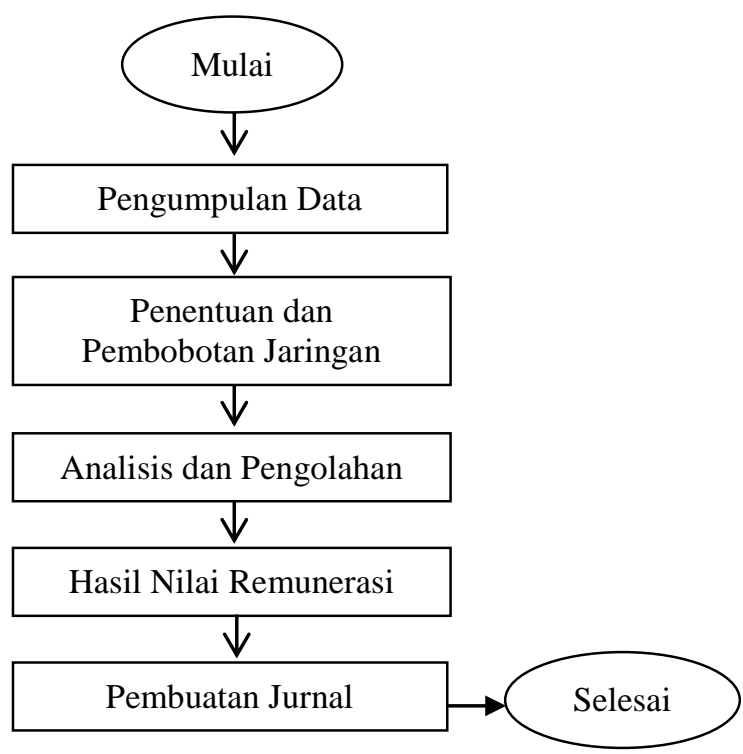

Gambar 4. Tahapan Penelitian

\section{HASIL PENELITIAN}

Penelitian ini diawali dengan pengumpulan data/informasi yang mempengaruhi besaran gaji remunerasi pada PN Kelas I B.

Tabel 1. Tunjangan Jabatan

\begin{tabular}{cllc}
\hline NO & NAMA & JABATAN & $\begin{array}{c}\text { TUNJANGAN } \\
\text { JABATAN }\end{array}$ \\
\hline 1 & ANDI & Eselon 2 & 500,000 \\
2 & ANA & Eselon 3 & 500,000 \\
3 & BUDI & Eselon 4 & 275,000 \\
\hline
\end{tabular}

Tabel 2. Potongan Remunerasi

\begin{tabular}{|c|c|c|c|}
\hline NO & $\begin{array}{l}\text { PENYEBAB } \\
\text { POTONGAN }\end{array}$ & $\begin{array}{l}\text { JUMLAH } \\
\text { HADIR }\end{array}$ & POTONGAN \\
\hline 1 & TIDAK HADIR & 1 hari & $5 \%$ \\
\hline 2 & SAKIT & $>5$ hari/thn & $5 \%$ \\
\hline 3 & IZIN & 1 hari & $5 \%$ \\
\hline 4 & CUTI & $>8$ hari & $5 \%$ \\
\hline 5 & $\begin{array}{l}\text { DATANG } \\
\text { TERLAMBAT }\end{array}$ & \pm 15 menit & $1 \%$ \\
\hline 6 & $\begin{array}{l}\text { CEPAT } \\
\text { PULANG }\end{array}$ & \pm 15 menit & $1 \%$ \\
\hline 7 & $\begin{array}{l}\text { CUTI ALASAN } \\
\text { PENTING }\end{array}$ & 1 hari & $1 \%$ \\
\hline
\end{tabular}

Metode JST yang digunakan adalah model Backpropagation. Pada perancangan ini, model jaringan syaraf tiruan terdiri dari 3 rancangan pokok yaitu :

a) Input

- Proses input atau masukan dilakukan dengan memasukkan data pegawai yang meliputi nama dan jabatan pegawai.

- Input berikutnya adalah memasukkan data kehadiran pegawai untuk periode satu bulan.

b) Output

- Hasil ouput keluaran adalah data pegawai yang meliputi nama dan jabatan pegawai.

- Hasil output keluaran adalah total gaji remunerasi yang diperoleh pegawai untuk periode satu bulan.

c) Arsitektur Jaringan

Arsitektur jaringan yang digunakan adalah jaringan lapisan tunggal atau yang biasa dikenal dengan sebutan single layer net yang diilustrasikan melalui tahapan dengan inisialisasi variable sebagai berikut :
$\mathrm{Nm}$ : Nama Pegawai
Gp : Gaji Pokok pegawai
Jab : Jabatan
Tjab : Tunjangan Jabatan
i : Jumlah lapisan tersembunyi
$\mathrm{x}$ : Penyebab potongan 


$$
\begin{array}{ll}
\mathrm{a} & : \text { Jumlah ketidakhadiran dalam sebulan } \\
\mathrm{b} & : \text { Potongan (dalam \%) } \\
\mathrm{Bp} & : \text { Besarnya potongan } \\
\mathrm{Ra} & : \text { Nilai Remunerasi awal/mula-mula } \\
\mathrm{Rt} & : \text { Total Remunerasi yang diterima pegawai }
\end{array}
$$

Data yang dimasukkan kemudian akan diproses

$$
B p=\operatorname{Rax} \sum_{i=1}^{n} \mathrm{axb}
$$

Dimana nilai Ra diperoleh dari perhitungan berikut :

$$
R a=(G p \times 70 \%)+T j a b
$$

Sehingga diperoleh besarnya gaji remunerasi total yang diperoleh oleh pegawai dalam lingkup PN kelas 1B adalah :

$$
R t=R a-B p
$$

\section{KESIMPULAN}

Perhitungan gaji remunerasi pada PN Kelas 1B dapat pula diaplikasikan pada perhitungan remunerasi Pengadilan Tinggi Negeri (PTN) atau PN kelas 1A, hanya saja yang perlu dimodifikasi adalah besarnya nilai tunjangan jabatan. Adapun metode JST yang dibangun menggunakan arsitektur jaringan lapisan tunggal

\section{UCAPAN TERIMA KASIH}

Penulis ingin mengucapkan terimakasih kepada semua pihak yang sudah terlibat dalam pembuatan jurnal ini, tim ULP Unhas yang banyak membantu dalam pengambilan data, LPPM Unasman, rekan-rekan sejawat di Fakultas Ilmu Komputer Unasman, serta seluruh civitas akademis di Universitas Al Asyariah Unasman yang telah memberikan lingkungan kerja yang nyaman untuk mengembangkan proses penelitian bagi penulis.

\section{Daftar Pustaka}

[1] Abdul Kadir, Terra Ch. Triwahyuni., 2003, Pengenalan Teknologi Informasi dgn Sistem Pakar, Yogyakarta : Penerbit Andi Yogyakarta.

[2] Andrijasa MF, Mistianingsih., 2010, Penerapan Jaringan Syaraf Tiruan Untuk Memprediksi Jumlah Pengangguran di Kalimantan Timur Dengan Menggunakan Algoritma Pembelajaran Backpropagation.

[3] Bambang Sancoko., 2010, Pengaruh Remunerasi Terhadap Kualitas Pelayanan Publik.

[4] Handoko, T. Hani., 1987, Manajemen Personalia dan Sumberdaya Manusia Edisi 2, Yogyakarta. Penerbit : BPFE.

[5] Misail Palagia, dkk., 2012, Remunerasi, motovasi dan kepuasan kerja terhadap kinerja pegawai pada kantor pajak, Makassar.
[6] Kusumadewi, Sri., 2003 Artificial Intelligence (Teknik dan Aplikasinya), Yogyakarta : Penerbit Graha Ilmu.

[7] Putri Asmara CCI, dkk., 2012, Rancang Bangun Sistem Informasi Remunerasi Pada Instalasi Sistem Informasi Manajemen (SIM-RS) RSU Haji. Surabaya.

[8] Wikipedia. Jaringan Sarat Tiruan - Wikipedia, the free encyclopedia. http://id.wikipedia.org/wiki/Jaringan_saraf tirua n. Tanggal Akses: 20 November 2013, 2012.

[9] Wikipedia. Remunerasi. 2012. Remunerasi. http://id.wiktionary.org/wiki/remunerasi. Tanggal akses : 20 November 2013, 2012. 